\title{
Recognition of the mRNA selenocysteine insertion sequence by the specialized translational elongation factor SELB
}

\author{
Steven Ringquist, ${ }^{1}$ Dan Schneider, ${ }^{1}$ Terri Gibson, ${ }^{1}$ Christian Baron, ${ }^{2}$ August Böck, ${ }^{2}$ and \\ Larry Gold ${ }^{1,3}$ \\ ${ }^{1}$ Department of Molecular, Cellular, and Developmental Biology, University of Colorado, Boulder, Colorado 80309 USA; \\ ${ }^{2}$ Lehrstuhl für Mikrobiologie, der Universität München, W-8000 Munich 19, Germany
}

In Escherichia coli the unusual amino acid selenocysteine is incorporated cotranslationally at an in-frame UGA codon. Incorporation of selenocysteine relies, in part, on the interaction between a specialized elongation factor, the SELB protein, and a cis-acting element within the mRNA. Boundary and toeprint experiments illustrate that the SELB-GTP-Sec-tRNA ${ }^{\text {Sec }}$ ternary complex binds to the selenoprotein encoding mRNAs $f d h F$ and $f d n G$, serving to increase the concentration of SELB and Sec-tRNA ${ }^{\text {Sec }}$ on these mRNAs in vivo. Moreover, toeprint experiments indicate that SELB recognizes the ribosome-bound message and that, upon binding, SELB may protrude out of the ribosomal-mRNA track so as to approach the large ribosomal subunit. The results place the mRNA-bound SELB-GTP-Sec-tRNA ${ }^{\text {Sec }}$ ternary complex at the selenocysteine codon (as expected) and suggest a mechanism to explain the specificity of selenocysteine insertion. Cis-acting mRNA regulatory elements can tether protein factors to the translation complex during protein synthesis.

[Key Words: Selenoprotein; protein synthesis; ribosomes; translation; toeprinting]

Received September 29, 1993; revised version accepted December 21, 1993.

The micronutrient selenium is an essential element in mammals and bacteria (Pinsent 1954; Schwarz and Foltz 1957). Selenium has been identified as a covalent base modification in tRNA from bacteria as well as mammals (Chen and Stadtman 1980; Ching and Stadtman 1982; Ching 1984; Wittwer et al. 1984; Wittwer and Ching 1989; Kramer and Ames 1988; Ching 1984) and is incorporated into protein cotranslationally as the amino acid selenocysteine (Cone et al. 1976; Forstrom et al. 1978; Stadtman 1990; Böck et al. 1991|. Selenoproteins typically contain one selenocysteine moiety per peptide chain although the mammalian plasma protein, selenoprotein $\mathrm{P}$, has been reported to have as many as 10 selenocysteine residues (Hill et al. 1991, 1993). Other examples of selenoproteins include the three coordinately expressed formate dehydrogenases from Escherichia coli (Berg et al. 1991a; Sawers et al. 1991) as well as glutathione peroxidase and type I tetraiodothyronine deiodinase from mammals (Forstrom et al. 1978; Stadtman 1990; Berry et al. 1991). In general, these enzymes catalyze oxidation-reduction reactions, sometimes acting as peroxide scavengers (for recent reviews, see Stadtman 1990; Böck et al. 1991; Burk 1991) and share the common feature that the selenocysteine residue has been implicated during catalysis (Wu and Hilvert 1989; Arkowitz and Abeles 1990; Stadtman 1990; Axley et al. 1991).

${ }^{3}$ Corresponding author.
Some of the signals directing selenoprotein synthesis in $E$. coli as well as mammals have been identified. Selenocysteine is incorporated cotranslationally at a specific, in-frame UGA codon; recoding of UGA from nonsense to selenocysteine requires the action of the selenocysteine insertion sequence (SECIS), a cis-acting mRNA element (Berg et al. 1991a,b; Berry et al. 1991; Heider et al. 1992; Hill et al. 1993). In E. coli a number of additional selenocysteine specific factors have also been characterized. Selenoprotein synthesis relies on a unique tRNA (Lee et al. 1989, 1990; Leinfelder et al. 1988a, 1989, 1990; Baron and Böck 1991; Li and Yarus 1992; Baron et al. 1993a) and three protein gene products (Leinfelder et al. 1988b; Böck and Stadtman 1988). One of these, the SELB protein, resembles EFTu in sequence as well as function (Leinfelder et al. 1989; Forchhammer et al. 1989,1990 ) and may play a crucial role during translational incorporation of selenocysteine. Moreover, SELB binds the mRNA SECIS (Baron et al. 1993b) and may directly regulate decoding of a specific UGA codon from nonsense to selenocysteine.

The present work uses toeprinting and boundary assays to identify the SELB-binding site on two selenoprotein encoding mRNAs from $E$. coli and investigates the interaction of SELB with the translational initiation complex. We used an RNA construct containing an AUG.UGA immediately adjacent to the SECIS so as to align the AUG.UGA codons with the ribosomal $\mathrm{P}$ and $\mathrm{A}$ 
sites and mimic the natural selenocysteine accepting complex. In agreement with our previous report (Ringquist et al. 1993a), toeprint experiments indicate that the SECISs from both mRNAs retained their secondary structure when bound to the ribosomal-mRNA track. The data also indicate that SELB protein binds within the highly structured SECIS, even in the presence of prebound ribosome and suggest that formation of the SELB-mRNA-ribosome complex may be an essential step during selenocysteine incorporation in vivo. Binding of SELB to the SECIS may serve to tether it to the translational complex, thus regulating the decoding of a specific, adjacent UGA codon.

\section{Results}

The interaction between purified SELB protein, 30S ribosome, and the SECISs from the selenoprotein encoding mRNAs $f d h F$ and $f d n G$ was examined by toeprinting and boundary assays. The RNAs are illustrated in Figure 1 and contain the naturally occurring SECIS (shaded) along with a strong ribosome-binding site (RBS). The RBSs were designed so that during toeprint experiments the AUG and UGA codons could be aligned with the ribosomal $\mathrm{P}$ and $\mathrm{A}$ sites, respectively. This arrangement utilizes a bound $\mathrm{tRNA}_{\mathrm{f}}{ }^{\text {Met }}$ as the analogue of a peptidyltRNA held in the ribosomal $P$ site when the specific UGA is about to be recoded to selenocysteine.

\section{Determination of the SELB-mRNA binding site}

The SELB-mRNA binding site was determined by incubating partially hydrolyzed, $\left[{ }^{32} \mathrm{P}\right]$-end-labeled RNA with SELB protein followed by nitrocellulose filtration to separate bound from unbound RNA. The data, given in Figure 2, identify the $5^{\prime}$ and $3^{\prime}$ boundaries of the binding sequence within the $f d h F$ and $f d n G$ mRNAs. Each RNA gave a strong as well as an adjacent, weaker boundary. The strong and weak boundaries probably reflect differences in affinity of SELB for the RNA when the binding site is truncated by one nucleotide. The extra pair of bands observed when the $f d n G$ RNA $5^{\prime}$ boundary was determined probably represent a contaminating RNase because a band at this position and with increased intensity was also observed upon examination of the $3^{\prime}$ boundary. Comparison of the $f d h F$ and $f d n G$ boundary data indicates that the SELB-binding sites are at homologous positions on these mRNAs even though the sequences within the boundaries are different (Fig. 3). This was surprising first because selenocysteine incorporation in vivo is extremely sensitive to changes in the sequence of the SECIS (Heider et al. 1992) and second because a single base change within the loop region of the $f d h F$ SECIS resulted in decreased binding of SELB in vitro (Baron et al. 1993b). Apparently, binding of SELB to the SECIS can be salvaged by multiple, naturally occurring base changes suggesting that it may be an important property of RNA of different sequence to fold into structures with similar function (Tuerk and Gold 1990).

\section{Toeprinting of SELB at the SECIS}

Primer-extension inhibition analysis (toeprinting) identifies the position of site-bound protein on an RNA, relying on the ability of protein-RNA complexes to inhibit cDNA synthesis (Hartz et al. 1988). Toeprinting was used to investigate the interaction between the SECIS and SELB protein (Fig. 4). By itself, SELB toeprinted a single site on the SECISs from RNAs $f d h F$ and $f d n G$, representing only the second example (after the ribosomel of a toeprintable protein-RNA complex. SELB toeprinted the natural SECISs at the $3^{\prime}$-edge of the boundary sequence (see Fig. 2), and correlated the toeprint site to the $3^{\prime}$-edge of the SELB-mRNA complex. In contrast, the mutant SECIS, G25C, gave no toeprint (Fig. 4). Failure of this sequence to encode selenocysteine in vivo (Heider et al. 1992) and weak binding to SELB in vitro during mobility-shift assays (Baron et al. 1993b) suggest that the toeprint reflects the biologically important complex.

Toeprint experiments were also performed with the SELB-GTP-Sec-tRNA ${ }^{\text {Sec }}$ ternary complex (data not shown). These experiments were performed anaerobically because the selenocysteine residue is oxygen labile (Cone et al. 1976). Importantly, the SELB-GTP-SectRNA $^{\text {Sec }}$ ternary complex gave the same toeprint observed with SELB alone and did not toeprint the G25C mutant. Moreover, the same concentration of SELB was required to toeprint the $f d h F$ SECIS that was reported in the previous experiments (Fig. 4). In contrast, Baron et al. (1993b) observed enhanced binding of SELB to the SECIS in the presence of GTP and Sec-tRNA ${ }^{\text {Sec }}$. These results differ possibly because the mobility-shift assay employed by Baron et al. (1993b) and the toeprint assay may examine different kinetic properties of the SELB-mRNA complex (Ringquist et al. 1993b; Spedding et al. 1993); perhaps, the mobility-shift assay is more sensitive than toeprinting to changes in the off-rate of the SELB-mRNA or SELB-tRNA-mRNA complex.

\section{Toeprinting of the 30 S ribosome at the SECIS}

Toeprinting was also used to investigate the interaction between the $30 \mathrm{~S}$ ribosome and the SECIS. RNAs containing a strong RBS adjacent to the SECIS from the $E$. coli messages $f d h F$ or $f d n G$ were examined (Fig. 5). When tRNA $_{f}{ }^{\text {Met }}$ was present, and the AUG and UGA codons were aligned with the ribosomal $P$ and $A$ sites, the $30 S$ ribosome toeprinted these RNAs at two positions in agreement with results described previously by Ringquist et al. (1993a). The ribosome toeprinted the mRNAs at +16 and at an extended-toeprint site well beyond the expected limit of the ribosomal-mRNA track (Kang and Cantor 1985). The extended toeprints were sensitive to temperature as well as reverse transcriptase concentration (Ringquist et al. 1993a) and, surprisingly, would have been 14 nucleotides from the start codon if either of the SECIS-associated stem-loops were deleted. The sensitivity of the extended toeprint to reverse transcriptase activity may indicate that multiple toeprints can originate from a single protein-RNA com- 


\section{Ringquist et al.}
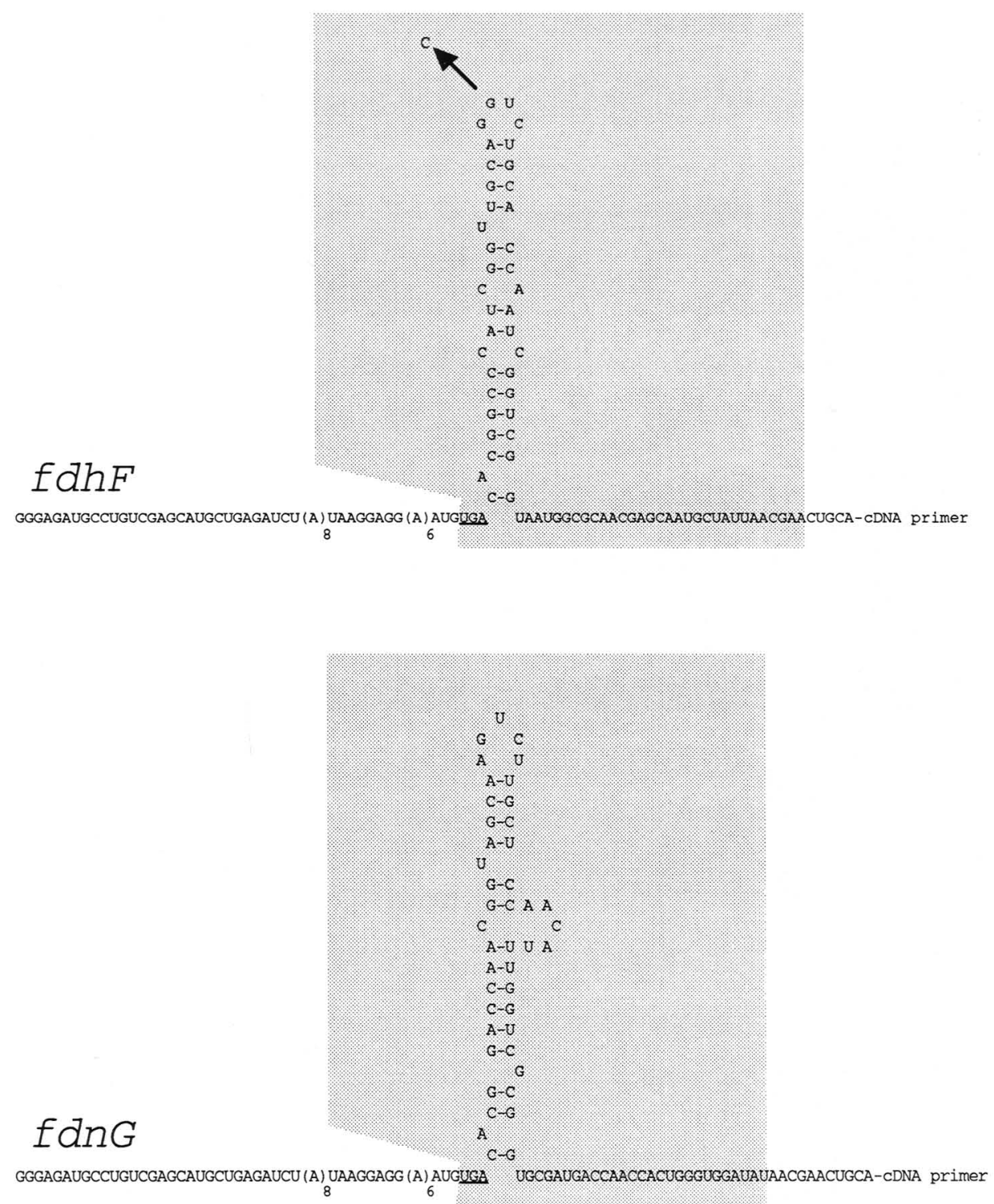

\section{RNA A}

GGGAGAUGCCUGUCGAGCAUGCUGAGAUCU (A) UAAGGAGG (A) AUGUGAGCAACGAGCAAUGCUAUUAACGAACUGCA-CDNA primer

Figure 1. Nucleotide sequence of the RNAs used in this study. In RNAs $f d h F$ and $f d n G$ the SECIS element is shaded, whereas the UGA codon is underlined. RNA G25C is a mutant of the fdhF RNA, and the position of the mutation is indicated.

plex. The +16 toeprint is a hard stop (independent of the reverse transcription activity/ suggesting that the mRNA secondary structure unfolds during cDNA synthesis (Ringquist et al. 1993a). Moreover, toeprinting of $70 \mathrm{~S}$ ribosomes also resulted in an extended-toeprint signal at this position (see Fig. 6). The unusual interaction between ribosome and SECIS was also investigated with the G25C mutant. This RNA exhibited the same extended toeprint as the native $f d h F$ SECIS, indicating that the extended toeprint, unlike SELB binding, was unaf- fected by the mutation (Fig. 5). The multiple toeprint bands associated with the extended toeprint may, in part, be due to heterogeneity in the position of the ribosome-SECIS-tRNA ${ }_{f}{ }^{\text {Met }}$ ternary complex because the RBS contained unavoidably overlapping AUG and GUG codons.

Toeprint experiments were also performed with ribosome and tRNA ${ }^{\text {Sec }}$ (Fig. 5). Complex formation was expected to align the UGA codon with the ribosomal $P$ site and might have examined whether secondary structure 


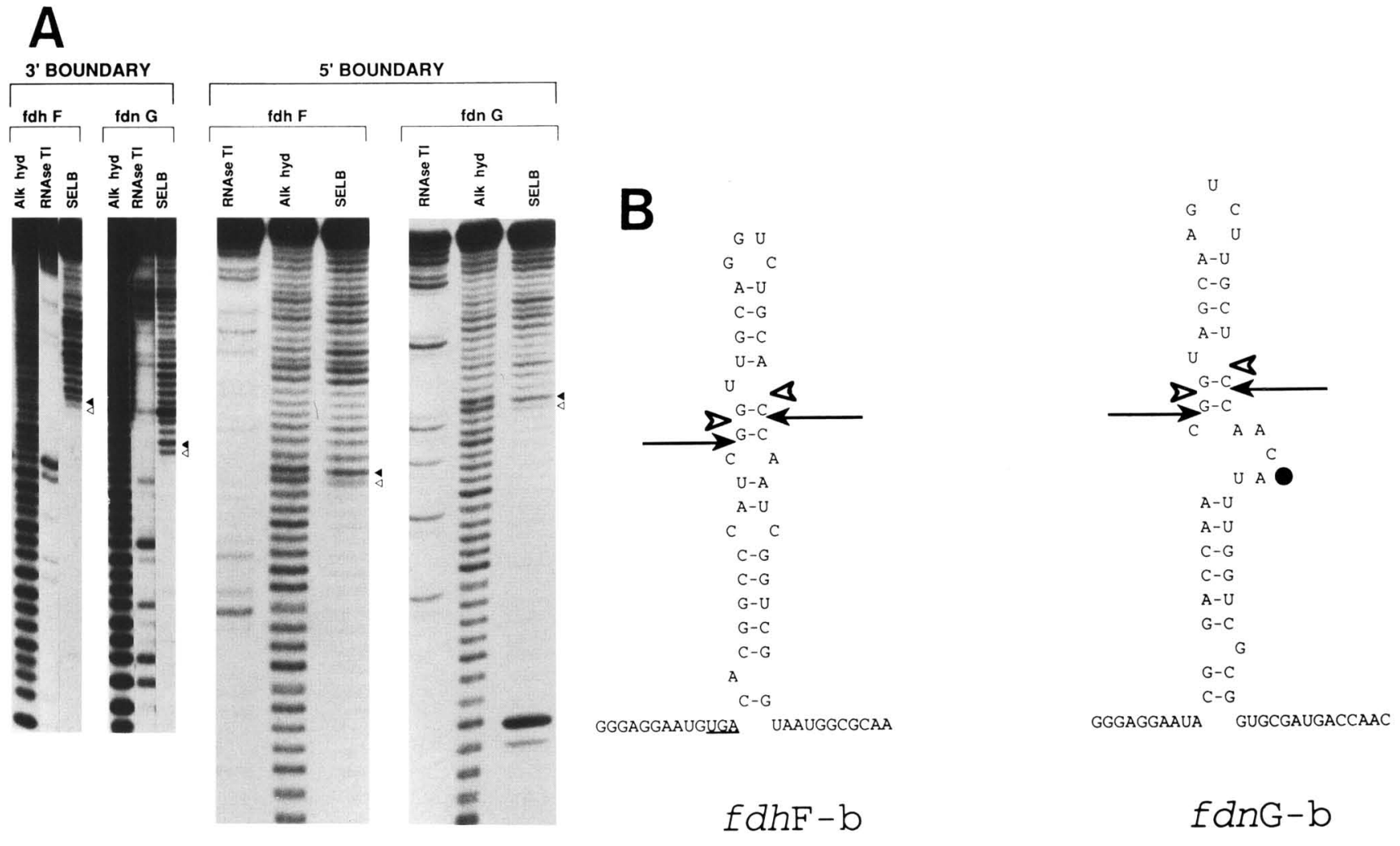

Figure 2. Boundary determination of the SELB-binding site on the $f d h F$ and $f d n G$ RNAs. $(A) 3^{\prime}$ and $5^{\prime}$ boundaries. In each panel, the partial RNase T1 digestion, alkaline hydrolysis, and SELB boundary lanes are indicated. SELB and RNA were present at 20 and $150 \mathrm{nM}$, respectively. $(B)$ Summary of the $3^{\prime}$ and $5^{\prime}$ boundary sites on the two RNAs. Closed and open arrows represent the position of the strong and weak boundaries, respectively. The closed circle indicates the position of the possible RNase cleavage.

associated with the SECIS could form when aligned with the A site. Toeprint experiments with $\mathrm{tRNA}^{\mathrm{Sec}}$ did not result in an extended toeprint or the +16 toeprint when the SECIS-containing mRNA was examined (Fig. 5). However, a control RNA lacking the SECIS did toeprint, perhaps suggesting that mRNA secondary structure associated with the SECIS may extend into the UGA codon and inhibit codon-anticodon pairing. A similar result was observed for a UGA supressor tRNA (Rafferty et al. 1984) (K. Beyser, unpubl.), indicating that the failure of the ribosome to toeprint the SECIS-containing mRNA reflects the position of the stem-loop structure within the ribosomal-mRNA track and is probably not affected by the selenocysteine specific tRNA.

\section{$S E L B$ binding to the preformed} ribosome-tRNA ${ }_{f}^{\text {Met }}$-SECIS complex

Toeprinting was used to investigate the effect of SELB on the extended toeprint from the ribosome-SECIStRNA $_{f}$ Met complex when the $f d h F$ RNA was presaturated with ribosomes (Fig. 6). Upon addition of SELB protein to the toeprint reaction, the intensity of the extended toeprint signal remained constant, whereas the signal from the +16 toeprint decreased. This may reflect loading of SELB protein onto the ribosome-SECIS-tR-

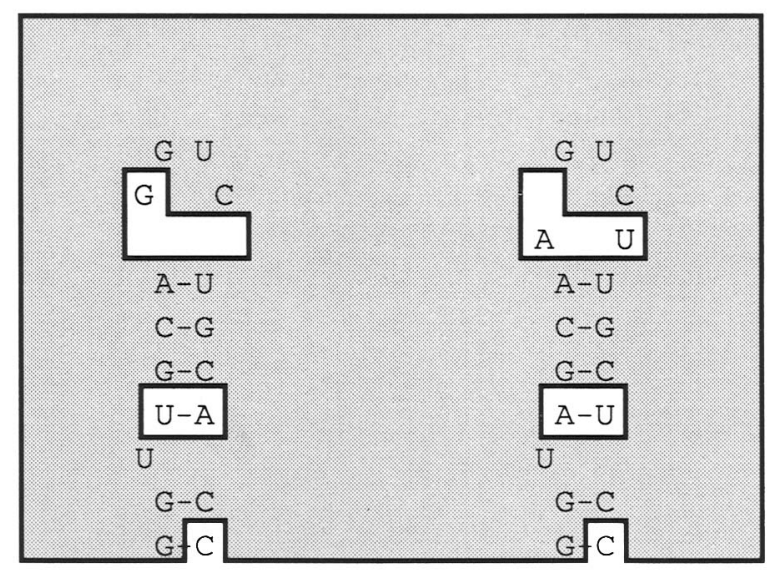

fdhF stem-1oop

fdnG stem-loop

Figure 3. Comparison of the SELB binding site on the $f d h F$ and $f d n G$ RNAs. Shaded region denotes the $3^{\prime}$ and $5^{\prime}$ boundary of the SELB-binding site whereas open boxes emphasize differences between these sequences. 

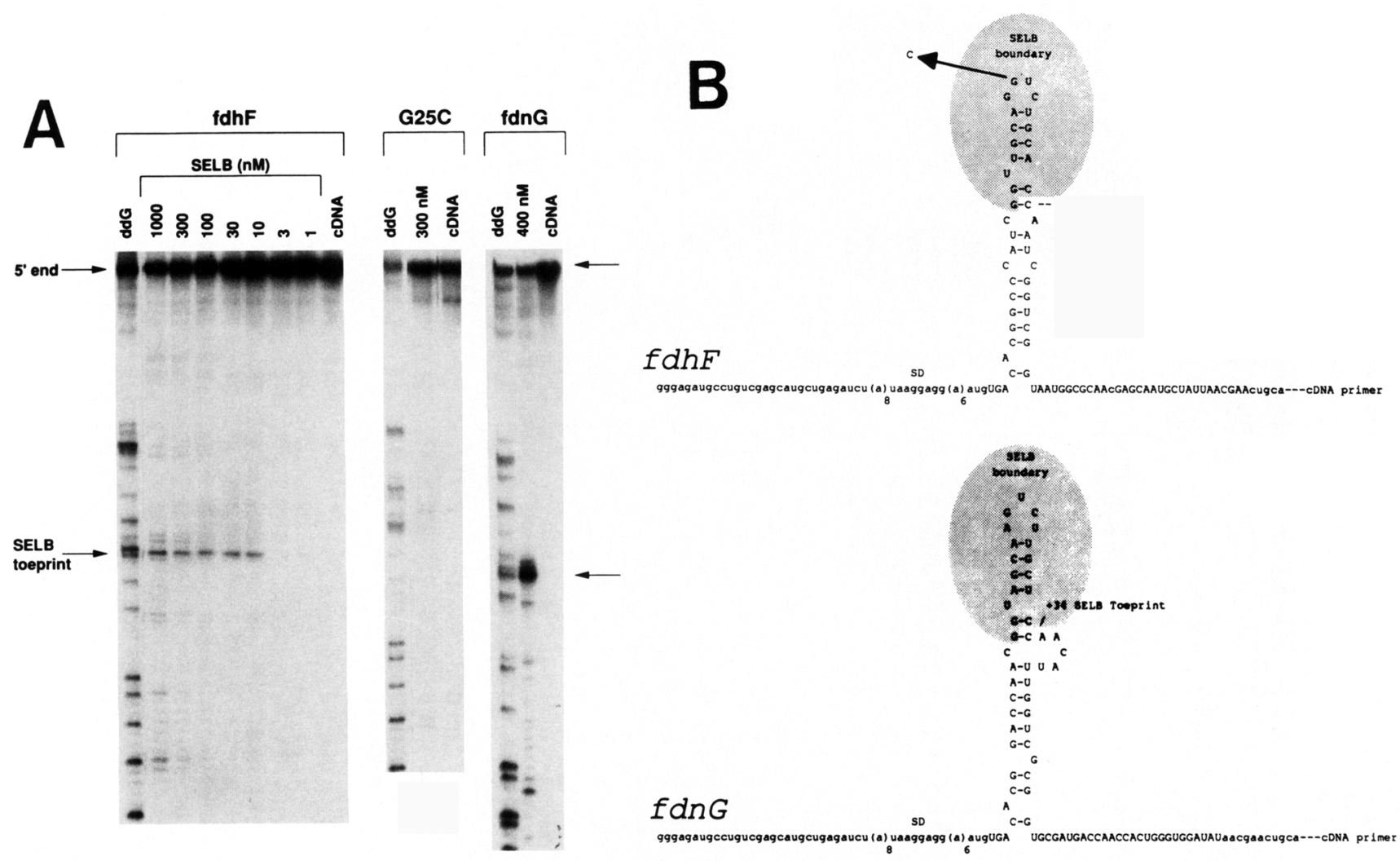

Figure 4. SELB toeprinted the natural SECISs at the 3 '-edge of the boundary site. $(A)$ Toeprint analysis of the $f d h F, \mathrm{G} 25 \mathrm{C}$, and $f d n G$ RNAs with SELB. The concentration of SELB was varied between 1000 and $1 \mathrm{nM}$ as indicated, and cDNA extension was performed at $23^{\circ} \mathrm{C}$ for 15 min with 20 units of M-MLV reverse transcriptase. The concentration of RNA was 8 nM. The ddG sequence and toeprint lanes are indicated. $(B)$ Summary of the SELB toeprint data. The SELB toeprint sites are indicated along with the site of the G25C mutation. The shaded region denotes the boundaries of the SELB binding site.

$\mathrm{NA}_{\mathrm{f}}^{\text {Met }}$ complex because the G25C RNA was unaffected. Overall, the results indicate that the ribosomal-mRNA track can easily accommodate the structured mRNA and simultaneously bind SELB to the loop region of the SECIS. Interestingly, the stem-loop structure associated with the SECIS may be as long as the tRNA ${ }^{\mathrm{Sec}}$ (Baron et al. 1993a), suggesting that in vivo the SELB-GTP-SectRNA $^{\text {Sec }}$ ternary complex could bind the SECIS and simultaneously allow anticodon-codon pairing at the ribosomal A site. The specific interaction between ribosome, SECIS, and SELB observed here suggests that tethering of protein factors to the translation complex may regulate selenoprotein synthesis.

\section{Discussion}

In E. coli, co-translational insertion of selenocysteine requires the presence of SELB (Forchhammer et al. 1989, 1990), a unique tRNA (Leinfelder et al. 1988a, 1989, 1990), and a cis-acting mRNA element (Zinoni et al. 1990). The mechanism by which SELB participates in selenoprotein synthesis has been analyzed by boundary as well as toeprint experiments (see above), mobilityshift assays (Baron et al. 1993b), and genetic analysis (Leinfelder et al. 1988b, 1989; Sawers et al. 1991). The data suggest that the SELB-GTP-Sec-tRNA ${ }^{\text {Sec }}$ ternary complex binds within the SECIS and that binding occurs even when the SECIS is saturated with ribosome.

Toeprint experiments also indicated that the interaction between the ribosome and the SECIS extend beyond the usual 15 nucleotides observed for the ribosomemRNA track (Ringquist et al. 1993a). The extended toeprint was positioned far from the RBS but, interestingly, would have been +14 nucleotides from the start codon if the proposed SECIS stem-loop structure were deleted. The extended toeprints were sensitive to reverse transcriptase concentration as well as reaction temperature (Ringquist et al. 1993a), suggesting that they represent weak interactions that are sensitive to reverse transcriptase activity. In contrast, the +16 toeprints usually observed for ribosome binding were unaffected by these variables (Spedding et al. 1993; Ringquist et al. 1993b). Moreover, three-dimensional models of the ribosome have indicated the presence of a large channel between the 30S and 50S subunits (Frank et al. 1992). The extended toeprint may represent a unique arrangement of ribosome and mRNA in which mRNA secondary structure extends into the solvent (Gold 1988).

The stable secondary structure of the SECIS may allow, simultaneously, the SELB-binding site to protrude 

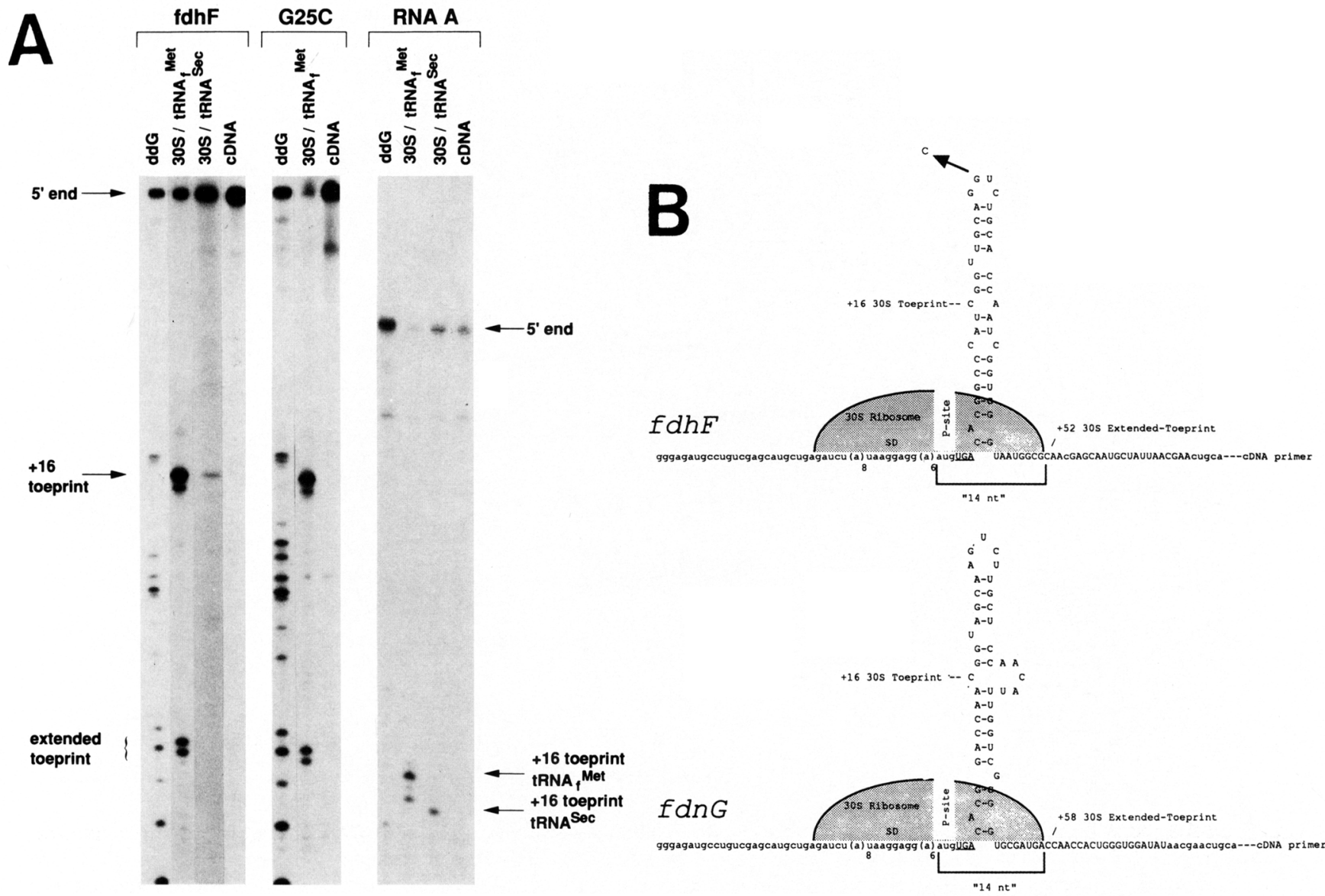

Figure 5. The $30 \mathrm{~S}$ ribosome toeprinted the natural SECISs from $f d h F$ and $f d n G$ at two sites and was insensitive to the G25C mutation. (A) Toeprint data for RNAs $f d h F$, G25C, and RNA A. The ddG sequence, cDNA extension control, and ribosome toeprint lanes are

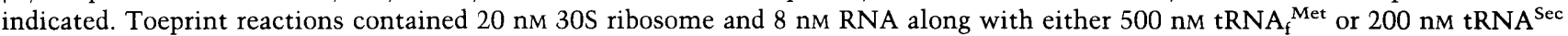
as indicated. cDNA extension used 20 units of M-MLV reverse transcriptase, and the reaction temperature was $23^{\circ} \mathrm{C}$. When tRNA ${ }^{\mathrm{Sec}}$ was present, cDNA extension was performed with 2 units of AMV reverse transcriptase at $23^{\circ} \mathrm{C}$. $(B)$ Summary of the ribosome toeprint data for RNAs $f d h F, \mathrm{G} 25 \mathrm{C}$, and $f d n G$ when $\mathrm{tRNA}_{\mathrm{f}}^{\text {Met }}$ was used.

into the channel between the ribosomal subunits and binding of the surrounding sequence within the ribosomal--mRNA track (Fig. 7). This architecture would place site-bound SELB-GTP-Sec-tRNA ${ }^{\text {Sec }}$ in a favorable position to interact with the approaching ribosomal A site. Interestingly, Heider et al. (1992) have shown that when the SECIS is truncated it no longer encodes selenocysteine, possibly because the SELB-GTP-Sec-tRNA ${ }^{\text {Sec }}$ complex no longer reaches into the ribosomal A site. Longer stems also reduce the efficiency of selenocysteine insertion (Heider et al. 1992), probably by increasing the search time for codon-anticodon pairing. The model also suggests that efficient competition between selenocysteine insertion and release factor RF2-mediated termination is accomplished by increasing the local concentration of the SELB-GTP-Sec-tRNA ${ }^{\text {Sec }}$ complex at a specific UGA codon (Zinoni et al. 1987; Baron et al. 1993b).

What other signals are required for recoding of the UGA codon from nonsense to selenocysteine? Surprisingly, the SELB-binding site on the $f d h F$ and $f d n G$ messages are substantially different. Yet, SELB binds these
RNAs tightly while unable to recognize single-site mutations within the $f d h F$ message (Heider et al. 1992; Baron et al. 1993b). Multiple, naturally occurring base changes between these messages may compensate for binding. Of course, the ability of message sequences to form stem-loop structures that have the same or similar roles in translation in spite of having very different base sequences need not be viewed as a result of multiple mutations. A similar situation has been described by Tuerk and Gold (1990) for RNA ligands generated in vitro to the bacteriophage T4 DNA polymerase suggesting that it may be a potential property of RNAs of different sequence to fold into homologous structures with similar function. Other features that may affect the interaction between site-bound SELB and the ribosomal A site include the length of the stem region of the SECIS as well as its position relative to the UGA codon (Heider et al. 1992). Each of these variables is likely to affect the rate of interaction between the SELB ternary complex and the ribosomal A site.

Other examples of cis-acting mRNA elements that 
Ringquist et al.

Figure 6. Complex formation between $70 \mathrm{~S}$ ribosome-tRNA ${ }_{f}{ }^{\text {Met }}$-RNA and SELB. (A) Toeprint data when $50 \mathrm{~S}$ ribosome, $30 \mathrm{~S}$ ribosome, and $\mathrm{tRNA}_{\mathrm{f}}{ }^{\text {Met }}$ were present at 50,20 , and $200 \mathrm{nM}$, respectively. Experiments were performed with $f d h F$ or G25C as indicated. The concentration of SELB was varied between 1000 and $1 \mathrm{nM}$ as indicated. $(B)$ Summary of the toeprint data when SELB, ribosome, mRNA, and tRNA $_{\mathrm{f}}^{\text {Met }}$ were present.
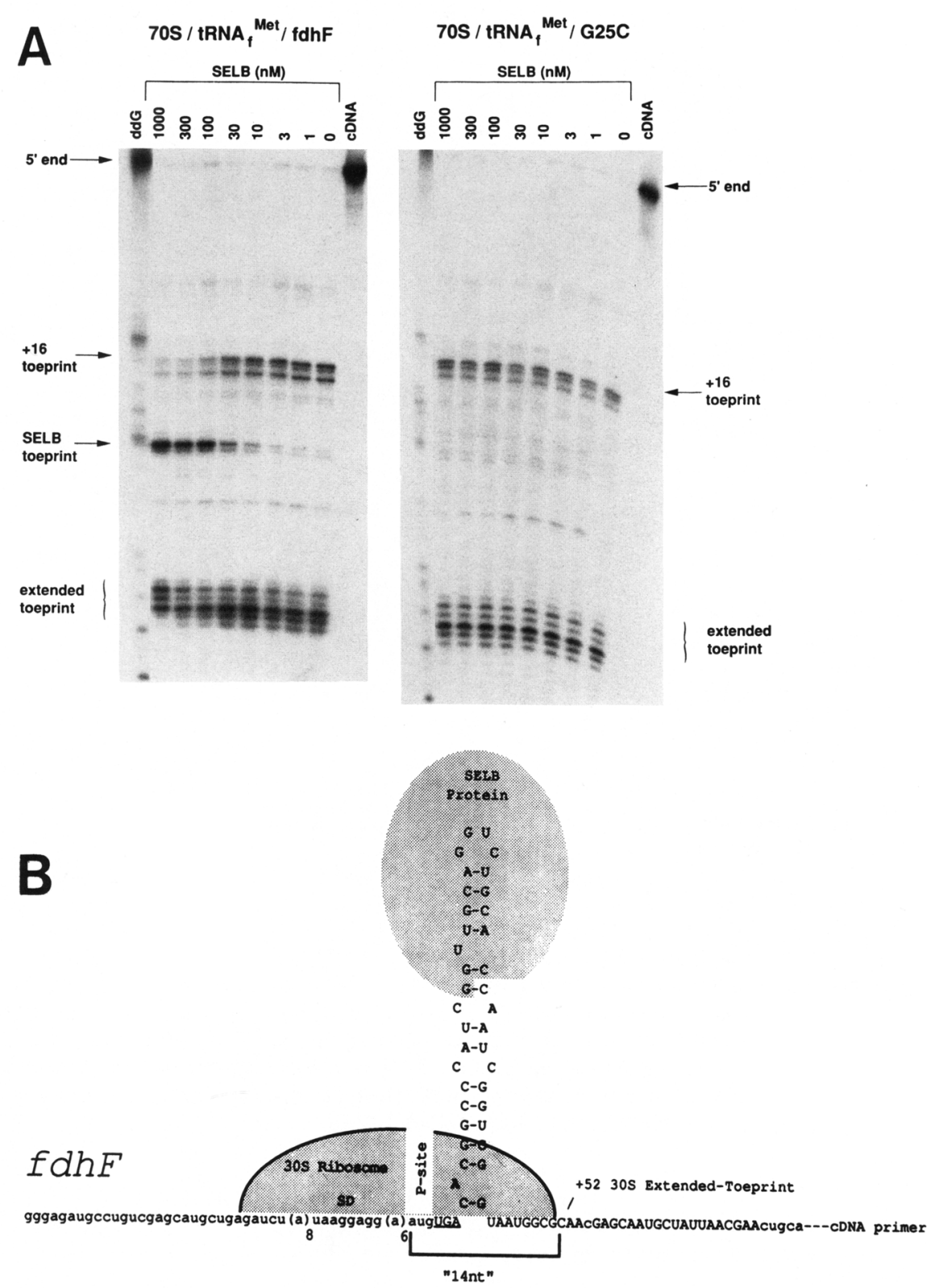

suppress nonsense codons have been described (Engelberg 1981; Dahlberg 1989; Brown et al. 1990; Rein and Levin 1992). For instance, the suppressible, in-frame UGA codon in the E. coli RF2 message is dependent on an adjacent Shine-Dalgarno-like element (Craigen et al. 1985; Curran and Yarus 1988), whereas the mammalian type $\mathrm{C}$ retroviruses also rely on a cis-acting mRNA element for recoding an in-frame UGA codon from nonsense to glutamate during synthesis of the gag-pol gene product (Rein and Levin 1992). Like selenocysteine, the type $\mathrm{C}$ retroviruses use a unique tRNA (Rein and Levin 1992) although specialized translation factors have not been identified. Elucidation of the mechanism by which a cis-acting mRNA element and a specialized elongation factor conspire to recode a UGA codon from nonsense to selenocysteine will lead to an enhanced understanding of the molecular mechanism by which the translation complex decodes the nucleotide message into protein.

\section{Materials and methods}

\section{Materials}

M-MLV reverse transcriptase was purchased from Bethesda Research Laboratories, AMV reverse transcriptase was from Life Sciences, Inc., T7 RNA polymerase was from U.S. Biochemicals Corporation, and Taq polymerase was from Promega Corporation. T4 polynucleotide kinase, alkaline phosphatase, and RNA ligase were purchased from New England Biolabs. tRNA ${ }_{f}{ }^{\text {Met }}$ was purchased from Subriden RNA (Rolling Bay, WA) whereas tRNA $^{\text {Sec }}$ was purified as described by Baron and Böck (1991). Purified SELB was obtained as described previously (Forchhammer et al. 1990). 30S ribosomes were a gift from R. Traut (Univ. 


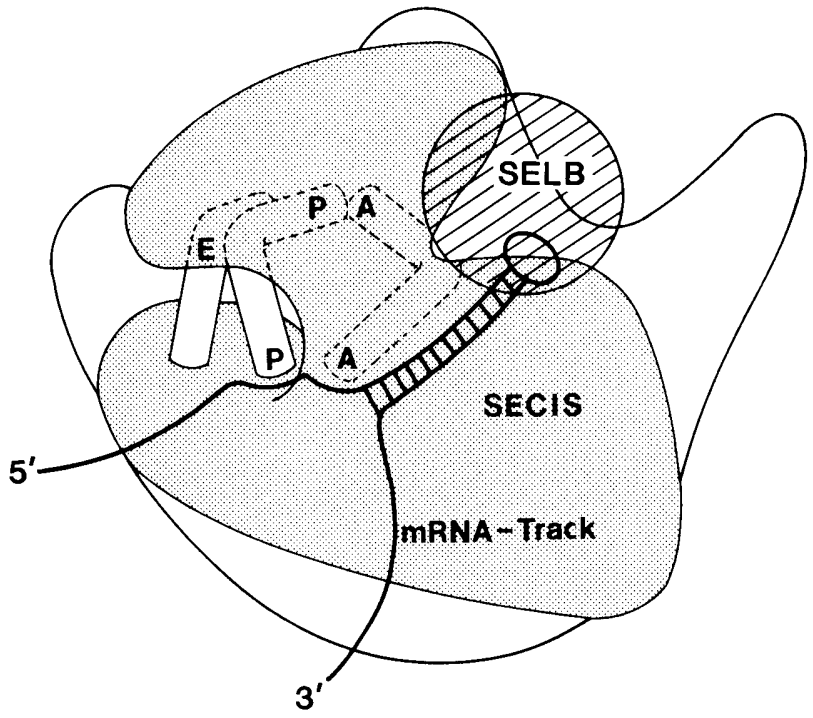

Figure 7. Model for the ribosome-SECIS-SELB complex. The ribosome structure was taken from Noller (1991) and is oriented so that the $30 \mathrm{~S}$ subunit (shaded) is in front. The plausible location of the ribosomal E, P, and A sites as well as the mRNA track and the SELB-SECIS complex are indicated.

of Calif., Davis|. Other reagents used in this work were of the highest quality obtainable.

\section{Nucleic acids}

RNAs were generated in vitro by transcription of PCR-amplified DNA oligonucleotides with T7 RNA polymerase. DNA oligonucleotides (Table 1) were synthesized on an Applied Biosystems Model 394 DNA/RNA synthesizer and purified by $6 \%$ preparative polyacrylamide gel electrophoresis. PCR amplification was performed in $50 \mathrm{mM} \mathrm{KCl}, 10 \mathrm{mM}$ Tris- $\mathrm{HCl}(\mathrm{pH} 8.6), 2.5$ $\mathrm{mM} \mathrm{MgCl}_{2}$, and $170 \mu \mathrm{g} / \mathrm{ml} \mathrm{BSA}$, and dNTPs were present at 1
mM each. Taq polymerase was used at 100 units per $0.1 \mathrm{ml}$ of reaction and the $5^{\prime}$ and $3^{\prime}$ primers were present at $1 \mu \mathrm{M}$. Transcription was performed in $8 \%$ PEG $8000,5 \mathrm{~mm}$ DTT, $40 \mathrm{~mm}$ Tris- $\mathrm{HCl}(\mathrm{pH} 8.0), 12 \mathrm{mM} \mathrm{MgCl}_{2}, 1 \mathrm{~mm}$ spermidine, $0.002 \%$ Triton X-100 and contained $2 \mathrm{~mm}$ NTPs. T7 RNA polymerase was present at a final concentration of $1 \mathrm{U} / \mu \mathrm{l}$. The reaction was incubated at $37^{\circ} \mathrm{C}$ for $2 \mathrm{hr}$ and then treated with 20 units of DNase I (New England Biolabs, Inc.) for an additional 5 min at $37^{\circ} \mathrm{C}$. The reaction was stopped by the addition of an equal volume of loading buffer [ $72 \%$ formamide, $120 \mathrm{mM}$ EDTA $/ \mathrm{pH}$ $8.0 \mathrm{O}]$ and heated to $60^{\circ} \mathrm{C}$ for $3 \mathrm{~min}$ prior to electrophoresis on a $6 \%$ polyacrylamide, $8 \mathrm{M}$ urea denaturing gel. The RNA transcript was visualized by UV shadowing, and the RNA band was excised from the gel and eluted into $\mathrm{dH}_{2} \mathrm{O}$. The RNA was then ethanol precipitated, dried under vacuum, and redissolved in $\mathrm{dH}_{2} \mathrm{O}$. The concentration of RNA was determined assuming one $A_{260}$ unit is equal to $40 \mu \mathrm{g} / \mathrm{ml}$.

\section{Boundary experiments}

The determination of the $5^{\prime}$ and $3^{\prime}$ boundaries of the SELB binding site was performed as described by Tuerk et al. (1990). Briefly, the RNA transcript was $5^{\prime}$-end-labeled by incubation with alkaline phosphatase ( 1 unit) at $37^{\circ} \mathrm{C} 30 \mathrm{~min}$ and subsequent treatment with polynucleotide kinase $(2$ units $)$ in the presence of $\left[\gamma^{32} \mathrm{P}\right] \mathrm{ATP}$ for $30 \mathrm{~min}$ at $37^{\circ} \mathrm{C}$. Labeling of the $3^{\prime}$-end with $\left(5^{\prime}-{ }^{32} \mathrm{P}\right) \mathrm{pCp}$ was performed with RNA ligase for $30 \mathrm{~min}$ at $37^{\circ} \mathrm{C}$. The $5^{\prime}$ - as well as $3^{\prime}$-labeled RNAs were band purified on a $6 \%$ polyacrylamide, $8 \mathrm{M}$ urea gel. End-labeled RNA 175 pmoles) was hydrolyzed in $50 \mathrm{mM} \mathrm{Na}_{2} \mathrm{CO}_{3}(\mathrm{pH} 9.0$ ) and $1 \mathrm{~mm}$ EDTA in a volume of $100 \mu \mathrm{l}$ for $10 \mathrm{~min}$ at $90^{\circ} \mathrm{C}$. The hydrolysis reaction was stopped by addition of $11 \mu \mathrm{l}$ of $3 \mathrm{M} \mathrm{Na}$-acetate $(\mathrm{pH}$ $5.2)$. Binding reactions were done with $20 \mathrm{nM}$ SELB protein in binding buffer $\left[50 \mathrm{mM} \mathrm{K} \mathrm{HPO}_{4} / \mathrm{KH}_{2} \mathrm{PO}_{4}(\mathrm{pH} 7.5), 2 \mathrm{mM} \mathrm{Mg}\right.$ acetate, $0.1 \mathrm{~mm}$ EDTA, $1 \mathrm{~mm}$ DTT, $0.5 \mathrm{~mm}$ GTP, $0.02 \%$ Tween$20]$ at $37^{\circ} \mathrm{C}$ for $5 \mathrm{~min}$. The concentration of hydrolyzed RNA was $150 \mathrm{~nm}$. Bound, end-labeled RNA was isolated from unbound RNA by filtration through nitrocellulose membranes (Millipore, Inc.), and rinsing with $5 \mathrm{ml}$ of wash buffer [50 mM Tris- $\mathrm{HCl}(\mathrm{pH}$ 7.5)]. The RNA was eluted from the filters by

Table 1. DNA oligonucleotides used in this study

\begin{tabular}{|c|c|}
\hline Oligonucleotide $^{\mathbf{a}}$ & Sequence $^{\mathrm{b}}$ \\
\hline $5 \mathrm{G} 3$ & 5'-CCGAAGCTTAATACGACTCACTATAGGGAGATGCCTGTCGAGCATGCTG-3' \\
\hline $3 \mathrm{G} 3$ & 5'-CCCGTCGACAAAGCTGTTTAGCTAC-3' \\
\hline $\mathrm{fdhF}$ & $\begin{array}{l}\text { 5'-CCCGTCGACAAAGCTGTTTAGCTACTGCAGTTCGTTAATAGCATTGCTCGTTGCGCCATTACCGACCGATTGGTGC } \\
\text { AGACCTGCAACCGATGGGCCGTGTCACAT(T) }\left.\right|_{6} \text { CCTCCTTA(T) }\left.\right|_{8} \text { AGATCTCAGCATGCTCGACAGGCATCTCCCTATAG } \\
\text { TGAGTCGTATTAAGCTTCGG-3' }\end{array}$ \\
\hline fdnG & $\begin{array}{l}\text { 5'-CCCGTCGACAAAGCTGTTTAGCTACTGCAGTTCGTTATATCCACCCAGTGGTTGGTCATCGCACCGCGACCAAATGT } \\
\text { TGGAGCAAGACTTGCTACCGTTGGTCCGTGTCACAT }(\mathrm{T})_{6} \text { CCTCCTTA }(\mathrm{T})_{8} \text { AGATCTCAGCATGCTCGACAGGCATCTC } \\
\text { CC-3' }\end{array}$ \\
\hline G25C & $\begin{array}{l}\text { 5'-CCCGTCGACAAAGCTGTTTAGCTACTGCAGTTCGTTAATAGCATTGCTCGTTGCGCCATTACCGACCGATTGGTGCA } \\
\text { GAGCTGCAACCGATGGGCCGTGTCACAT }(\mathrm{T})_{6} \text { CCTCCTTA }(\text { T) })_{8} \text { TAGATCTCAGCATGCTCGACAGGCATCTCCCTATAG } \\
\text { TGAGTCGTATTAAGCTTCGG-3' }\end{array}$ \\
\hline RNA A & $\begin{array}{l}\text { 5'-CCCGTCGACAAAGCTGTTTAGCTACTGCAGTTCGTTAATAGCATTGCTCGTTGCTCACAT(T) }{ }_{6} \mathrm{CCTCCTTA}(\mathrm{T})_{8} \text { AGATC } \\
\text { TCAGCATGCTCGACAGGCATCTCCCTATAGTGAGTCGTATTAAGCTTCGG-3' }\end{array}$ \\
\hline T7pts & 5'-CTTAATACGACTCACTATAGGG-3' \\
\hline fdhF-b & $\begin{array}{l}\text { 5'-TTGCGCCATTACCGACCGATTGGTGCAGACCTCAACCGATGGGCCGTGTCACATTCCTCCCTATAGTGAGTCGTATT } \\
\text { AAG-3' }\end{array}$ \\
\hline fdnG-b & $\begin{array}{l}\text { 5'-GTTGGTCATCGCACCGCGACCAAATGTTGGAGCAAGACTTGCTACCGTTGGTCCGTATTCCTCCCTATAGTGAGTCG } \\
\text { TATTAAG-3' }\end{array}$ \\
\hline
\end{tabular}

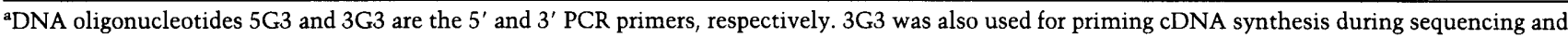
toeprinting. T7pts is the $5^{\prime}$ primer for transcription of DNA oligonucleotides fdhF-b and fdnG-b.

${ }^{b}$ The symbol $(T)_{n}$ represents the number of times $\mathrm{T}$ is repeated. 
incubation in an emulsion of $200 \mu \mathrm{l}$ of $7 \mathrm{M}$ urea, $400 \mu \mathrm{l}$ of phenol [equilibrated against $1 \mathrm{M}$ Tris- $\mathrm{HCl}(\mathrm{pH} 8.0)]$ for $30 \mathrm{~min}$ at room temperature. The urea/phenol emulsion was separated into phases by the addition of $200 \mu \mathrm{l}$ of chloroform followed by centrifugation. The aqueous phase was removed, and the RNA was precipitated upon the addition of $20 \mu \mathrm{l}$ of $3 \mathrm{M} \mathrm{Na}$-acetate, $20 \mu \mathrm{g}$ of carrier tRNA, and 2 volumes of ethanol. The pellet was washed once with $70 \%$ ethanol, dried, and resuspended in $5 \mu \mathrm{l}$ of $\mathrm{dH}_{2} \mathrm{O}$ followed by the addition of $5 \mu$ l formamide loading dye [72\% formamide, $120 \mathrm{~mm}$ EDTA ( $\mathrm{pH} 8.0$ )] prior to electrophoresis.

A sequence ladder of the $f d h F$ and $f d n G$ RNAs was generated by partial RNase $\mathrm{Tl}$ digestion. The RNase T1 digest was performed in a 10- $\mu$ l reaction containing 0.5 pmoles of end-labeled RNA and 10 units of RNase T1 (New England Biolabs, Inc.) in 7 $\mathrm{M}$ urea, $20 \mathrm{~mm}$ Na-citrate ( $\mathrm{pH}$ 5.0) and $1 \mathrm{~mm}$ EDTA. The RNA was incubated for $10 \mathrm{~min}$ at $50^{\circ} \mathrm{C}$ without enzyme and then another $10 \mathrm{~min}$ after addition of enzyme. The reaction was stopped by adding $10 \mu \mathrm{l}$ of loading buffer.

Formation of the SELB-GTP-Sec-tRNA ${ }^{\text {Sec }}$ ternary complex

The SELB-GTP-Sec-tRNA ${ }^{\text {Sec }}$ ternary complex was generated in an anaerobic atmosphere $\left(95 \% \mathrm{~N}_{2}, 5 \% \mathrm{H}_{2}\right)$ as described previously by Baron and Böck (1991). Briefly, seryl-tRNA ${ }^{\text {Sec }}$ was converted into selenocysteinyl-tRNA ${ }^{\text {Sec }}$ by incubating 200 pmoles of $\left[{ }^{14} \mathrm{C}\right]$ seryl-tRNA ${ }^{\mathrm{Sec}}(337 \mathrm{cpm} / \mathrm{pmole})$ with $25 \mu \mathrm{g} / \mathrm{ml}$ SELA protein and $38 \mu \mathrm{g} / \mathrm{ml}$ SELD protein in $100 \mathrm{mM}$ HEPES ( $\mathrm{pH} 7.0$ ), $20 \mathrm{~mm} \mathrm{KCl}, 5 \mathrm{~mm} \mathrm{Mg}$-acetate, $2 \mathrm{mM} \mathrm{DTT}, 20 \mu \mathrm{M} \mathrm{ATP}$, and 100 $\mu \mathrm{M} \mathrm{SeO}$ in a total volume of $200 \mu$ l. The reaction was performed at $37^{\circ} \mathrm{C}$ for $20 \mathrm{~min}$, and the efficiency of serine to selenocysteine conversion was monitored by thin layer chromatography (Baron and Böck 1991). Formation of the SELB-GTP-SectRNA $^{\mathrm{Sec}}$ ternary complex was performed by incubation of the individual components in the toeprinting buffer for $15 \mathrm{~min}$ at $37^{\circ} \mathrm{C}$. Complex formation was monitored by SELB-dependent protection of selenocysteinyl-tRNA ${ }^{\mathrm{Sec}}$, but not seryl-tRNA ${ }^{\mathrm{Sec}}$, to pancreatic RNase digestion (Baron and Böck 1991).

\section{Toeprinting}

Primer-extension inhibition (toeprinting) was performed as described by Hartz et al. (1988) with M-MLV or AMV reverse transcriptase as indicated in the Results. The $\left[{ }^{32} \mathrm{P}\right]$-labeled primer 3G3, which is complementary to the 3 '-end of the various RNA transcripts was annealed as described in Hartz et al. (1988). Toeprint reactions were performed in VDG buffer [10 $\mathrm{mm}$ Tris-acetate (pH 7.4), $60 \mathrm{mM} \mathrm{NH}_{4} \mathrm{Cl}, 10 \mathrm{~mm} \mathrm{Mg}$-acetate, 1 $\mathrm{mm}$ GTP, $6 \mathrm{~mm} \beta$-mercaptoethanol] and contained $8 \mathrm{~nm}$ RNA in a volume of $10 \mu \mathrm{l}$ along with 30S ribosome or SELB protein as specified in the Results. The reaction components were combined on ice and preincubated as indicated in the Results before addition of reverse transcriptase and incubation for an additional $15 \mathrm{~min}$. When selenocysteinyl-tRNA ${ }^{\mathrm{Sec}}$ was present toeprinting experiments were performed in an anaerobic atmosphere $\left(95 \% \mathrm{~N}_{2}, 5 \% \mathrm{H}_{2}\right)$.

\section{Acknowledgments}

We are grateful to Lori Weyant for preparation of the manuscript. S.R. thanks August Böck and friends for a pleasant visit to their laboratory. We thank the W.M. Keck Foundation for their generous support of RNA science on the Boulder campus. D.S. was supported, in part, by funds from Nexagen, Boulder, Colorado. This work was done under research grants from the National Institutes of Health to L.G. /GM-28685 and GM-19963/ and from the Bundesministerium für Forschung und Technologie and the Fonds der Chemischen Industrie to A.B.
The publication costs of this article were defrayed in part by payment of page charges. This article must therefore be hereby marked "advertisement" in accordance with 18 USC section 1734 solely to indicate this fact.

\section{References}

Arkowitz, R.A. and R.H. Abeles. 1990. Isolation and characterization of a covalent selenocysteine intermediate in the glycine reductase system. J. Am. Chem. Soc. 112: 870-872.

Axley, M.J., A. Böck, and T.C. Stadtman. 1991. Catalytic properties of an Escherichia coli formate dehydrogenase mutant in which sulfur replaces selenium. Proc. Natl. Acad. Sci. 88: $8450-8454$.

Baron, C. and A. Böck. 1991. The length of the aminoacyl-acceptor stem of the selenocysteine-specific tRNA ${ }^{\mathrm{Sec}}$ of Escherichia coli is the determinant for binding to elongation factors SELB and Tu. I. Biol. Chem. 266: 20375-20379.

Baron, C., E. Westhof, A. Böck, and R. Giege. 1993a. Solution structure of selenocysteine-inserting tRNA ${ }^{\mathrm{Sec}}$ from Escherichia coli: Comparison with canonical tRNA ${ }^{\text {Ser }}$. J. Mol. Biol. 231: 274-292.

Baron, C., J. Heider, and A. Böck. 1993b. Interaction of translation factor SELB with the FDHF selenopolypeptide mRNA. Proc. Natl. Acad. Sci. 90: 4181-4185.

Berg, B.L., J. Li, J. Heider, and V. Stewart. 1991a. Nitrate-inducible formate dehydrogenase in Escherichia coli K-12 I. Nucleotide sequence of the $f d n G D I$ operon and evidence that opal (UGA) encodes selenocysteine. I. Biol. Chem. 266: 22380-22385.

Berg, B.L., C. Baron, and V. Stewart. 1991b. Nitrate-inducible formate dehydrogenase in Escherichia coli K-12 II. Evidence that a mRNA stem-loop structure is essential for decoding opal (UGA) as selenocysteine. I Biol. Chem. 266: 2238623391.

Berry, M.J., L. Banu, Y. Chen, S.J. Mandel, J.D. Kieffer, J.W. Harney, and P.R. Larsen. 1991. Recognition of UGA as a selenocysteine codon in type I deiodinase requires sequences in the $3^{\prime}$ untranslated region. Nature 353: 273-276.

Böck, A. and T.C. Stadtman. 1988. Selenocysteine, a highly specific component of certain enzymes, is incorporated by a UGA-directed co-translational mechanism. Biofactors 1: 245-250.

Böck, A., K. Forchhammer, J. Heider, and C. Baron. 1991. Selenoprotein synthesis: An expansion of the genetic code. Trends Biochem. Sci. 16: 463-467.

Brown, C.M., P.A. Stockwell, N.A. Trotman, and W.P. Tate. 1990. The signal for the termination of protein synthesis in procaryotes. Nucleic Acids Res. 18: 2079-2086.

Burk, R.F. 1991. Molecular biology of selenium with implication for its metabolism. FASEB I. 5: 2274-2279.

Chen, C.S. and T. Stadtman. 1980. Selenium-containing tRNAs from Clostridium stricklandii: Cochromatography of one species with L-prolyl-tRNA. Proc. Natl. Acad. Sci. 77: 14031407.

Ching, W.M. 1984. Occurrence of selenium-containing tRNAs in mouse leukemia cells. Proc. Natl. Acad. Sci. 81:30103013.

Ching, W.M. and T. Stadtman. 1982. Selenium-containing tRNA $^{\text {Glu }}$ from Clostridium stricklandii: Correlation of aminoacylation with selenium content. Proc. Natl. Acad. Sci. 79: 374-377.

Cone, J.E., M. Del Rio, J.N. Davis, and T.C. Stadtman. 1976. Chemical characterization of the selenoprotein component of clostridial glycine reductase: Identification of selenocysteine as the organoselenium moiety. Proc. Natl. Acad. Sci. 
73: 2659-2663

Craigen, W.J., R.G. Cook, W.P. Tate, and C.T. Caskey. 1985. Bacterial peptide chain release factors: Conserved primary structure and possible frameshift regulation of release factor 2. Proc. Natl. Acad. Sci. 82: 3616-3620.

Curran, J.F. and M. Yarus. 1988. Use of tRNA suppressors to probe regulation of Escherichia coli release factor 2. I. Mol. Biol. 203: 75-83.

Dahlberg, A.E. 1989. The functional role of ribosomal RNA in protein synthesis. Cell 57: 525-529.

Engelberg, K.H. 1981. UGA suppression by normal tRNA ${ }^{\operatorname{Trp}}$ in Escherichia coli: Codon context effects. Nucleic Acids Res. 9: 983-991.

Forchhammer, K., W. Leinfelder, and A. Böck. 1989. Identification of a novel translation factor necessary for the incorporation of selenocysteine into protein. Nature 342: 453-456.

Forchhammer, K., K.-P. Rucknagel, and A. Böck. 1990. Purification and biochemical characterization of SELB, a translation factor involved in selenoprotein synthesis. $J$. Biol. Chem. 265: 9346-9350.

Forstrom, J.W., J.J. Zakowski, and A.L. Tappel. 1978. Identification of the catalytic site of rat liver glutathione peroxidase as selenocysteine. Biochemistry 17: 2639-2644.

Frank, J., P. Penszek, R. Grassucci, and S. Srivastova. 1991. Three-dimensional reconstruction of the $70 \mathrm{~S}$ Escherichia coli ribosome in ice: The distribution of ribosomal RNA. J. Cell Biol. 115: 597-605.

Gold, L. 1988. Posttranscriptional regulatory mechanisms in Escherichia coli. Annu. Rev. Biochem. 57: 199-233.

Hartz, D., D.S. McPheeters, R. Traut, and L. Gold. 1988. Extension inhibition analysis of translation initiation complexes. Methods Enzymol. 164: 419-425.

Heider, J., C. Baron, and A. Böck. 1992. Coding from a distance: Dissection of the mRNA determinants required for the incorporation of selenocysteine into protein. $E M B O / .11$ : 3759-3766.

Hill, K.E., R.S. Lloyd, J.G. Yang, R. Read, and R.F. Burk. 1991. The cDNA for rat selenoprotein $P$ contains 10 TGA codons in the open reading frame. J. Biol. Chem. 266: 10050-10053.

Hill, K.E., R.S. Lloyd, and R.F. Burk. 1993. Conserved nucleotide sequences in the open reading frame and $3^{\prime}$-untranslated region of selenoprotein P mRNA. Proc. Natl. Acad. Sci. 90: $537-541$.

Kang, C. and C.R. Cantor. 1985. Structure of ribosomal-bound messenger RNA as revealed by enzymatic accessibility studies. J. Mol. Biol. 181: 241-245.

Kramer, G.F. and B.N. Ames. 1988. Isolation and characterization of a selenium metabolism mutant of Salmonella typhimurium. J. Bacteriol. 170: 736-743.

Lee, B.J., P.J. Worland, J.N. Davis, T.C. Stadtman, and D. Hatfield. 1989. Identification of selenocysteinyl-tRNA ${ }^{\text {Ser }}$ in mammalian cells that recognizes the nonsense codon, UGA. J. Biol. Chem. 264: 9724-9727.

Lee, B.J., M. Rafagopalan, Y.S. Kim, K.H. You, K.B. Jacobson, and D. Hatfield. 1990. Selenocysteine tRNA ${ }^{[\mathrm{Sex}] \mathrm{Sec}}$ gene is ubiquitous within the animal kingdom. Mol. Cell. Biol. 10: 1940-1949.

Leinfelder, W., E. Zehelein, M.-A. Mandrand-Berthelot, and A. Böck. 1988a. Gene for a novel tRNA species that accepts L-serine and cotranslationally inserts selenocysteine. $\mathrm{Na}$ ture 331: 723-725.

Leinfelder, W., K. Forchhammer, F. Zinoni, G. Sawers, M.-A. Mandrand-Berthelot, and A. Böck. 1988b. Escherichia coli genes whose products are involved in selenium metabolism. I. Bacteriol. 170: 540-546.

Leinfelder, W., T.C. Stadtman, and A. Böck. 1989. Occurrence in vivo of selenocysteyl-tRNA ${ }^{\text {Ser }}{ }_{\text {UCA }}$ in Escherichia coli: Effect of sel mutations. J. Biol. Chem. 264: 9720-9723.

Leinfelder, W., K. Forchhammer, B. Veprek, E. Zehelein, and A. Böck. 1990. In vitro synthesis of selenocysteinyl-tRNA $A_{U C A}$ from seryl-tRNA ${ }_{U C A}$ : Involvement and characterization of the selD gene product. Proc. Natl. Acad. Sci. 87: 543-547.

Li, W.-Q. and M. Yarus. 1992. Bar to normal UGA translation by the selenocysteine tRNA. J. Mol. Biol. 233: 9-15.

Noller, H.F. 1991. Ribosomal RNA and translation. Annu. Rev. Biochem. 60: 191-227.

Pinsent, J. 1954. The need for selenite and molybdate by members of the coli-aerogenes group of bacteria. Biochem. $I$. 57: $10-16$.

Rafferty, L.A., J.B. Egan, S.W. Cline, and M. Yarus. 1984. Defined set of cloned termination suppressors: in vivo activity of isogenetic UAG, UAA, and UGA suppressor tRNAs. $J$. Bacteriol. 158: 849-859.

Rein, A. and J.G. Levin. 1992. Readthrough suppression in the mammalian type $C$ retroviruses and what it has taught us. New Biol. 4: 283-289.

Ringquist, S., M. MacDonald, T. Gibson, and L. Gold. 1993a. Nature of the ribosomal mRNA track: Analysis of ribosome binding sites containing different sequences and secondary structure. Biochemistry 32: 10254-10262.

Ringquist, S., P. Cunningham, C. Weitzmann, L. Formenoy, C. Pleij, J. Ofengand, and L. Gold. 1993b. Translation initiation complex formation with $30 \mathrm{~S}$ ribosomal particles mutated at conserved positions in the 3 '-minor domain of $16 \mathrm{~S}$ RNA. $J$. Mol. Biol. 234: 14-27.

Sawers, G., J. Heider, E. Zehelein, and A. Böck. 1991. Expression and operon structure of the sel genes of Escherichia coli and identification of a 3 rd selenium containing formate dehydrogenase isoenzyme. I. Bacteriol. 173: 4983-4993.

Schwarz, K. and C.M. Foltz. 1957. Selenium is an integral part of factor-3 against dietary necrotic liver degeneration. J. Am. Chem. Soc. 79: 3292-3293.

Spedding, G., G. Gluick, and D.E. Draper. 1993. Ribosome initiation complex formation with the pseudoknotted $\alpha$ operon messenger RNA. I. Mol. Biol. 229: 609-622.

Stadtman, T.C. 1990. Selenium biochemistry. Annu. Rev. Biochem. 59: 111-128.

Tuerk, C. and L. Gold. 1990. Systematic evolution of ligands by exponential enrichment: RNA ligands to bacteriophage T4 DNA polymerase. Science 249: 505-510.

Tuerk, C., S. Eddy, D. Parma, and L. Gold. 1990. Autogenous translational operator recognized by bacteriophage T4 DNA polymerase. I. Mol. Biol. 213: 749-761.

Wittwer, A.J. and W.-M. Ching. 1989. Selenium-containing tRNA $^{\text {Glu }}$ and tRNA ${ }^{\text {Lys }}$ from Escherichia coli: Purification, codon specificity and translational activity. BioFactors 2: $27-34$.

Wittwer, A.J., L. Tsai, W.-M. Ching, and T.C. Stadtman. 1984 Identification and synthesis of a naturally occurring selenonucleoside in bacterial tRNAs: 5-[(methylamino)methyl]-2selenouridine. Biochemistry 23: 4650-4655.

Wu, Z.-P. and D. Hilvert. 1989. Conversion of a protease into an acyl transferase: selenolsubtilisin. J. Am. Chem. Soc. 111: 4513-4514.

Zinoni, F., A. Birkmann, W. Leinfelder, and A. Böck. 1987. Cotranslational insertion of selenocysteine into formate dehydrogenase from Escherichia coli directed by a UGA codon. Proc. Natl. Acad. Sci. 84: 3156-3160.

Zinoni, F., J. Heider, and J. Böck. 1990. Features of the formate dehydrogenase mRNA necessary for decoding of the UGA codon as selenocysteine. Proc. Natl. Acad. Sci. 87: 4660 4664. 


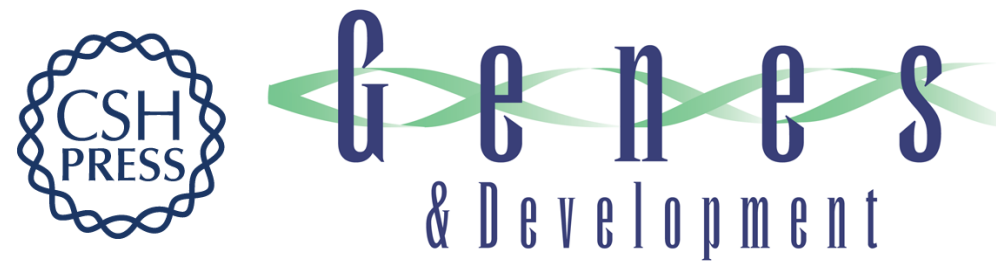

\section{Recognition of the mRNA selenocysteine insertion sequence by the specialized translational elongation factor SELB.}

S Ringquist, D Schneider, T Gibson, et al.

Genes Dev. 1994, 8:

Access the most recent version at doi:10.1101/gad.8.3.376

References This article cites 55 articles, 26 of which can be accessed free at:

http://genesdev.cshlp.org/content/8/3/376.full.html\#ref-list-1

License

Email Alerting

Service

Receive free email alerts when new articles cite this article - sign up in the box at the top right corner of the article or click here.

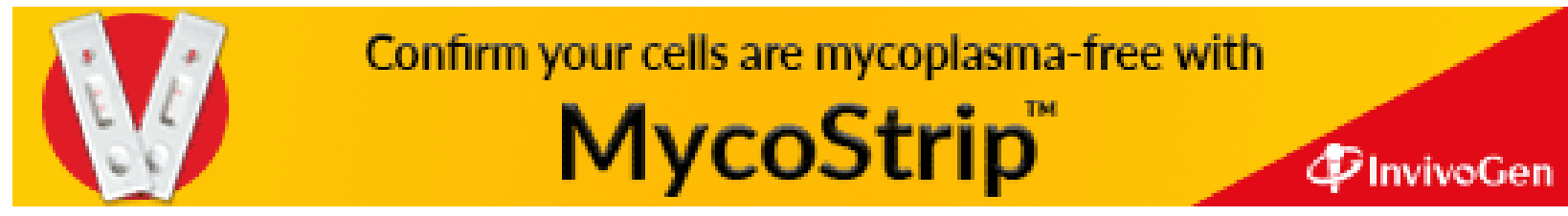

